\title{
Male vs. Female
}

\author{
By AlbReChT HoFHeINZ
}

"An unveiled woman is a threat to the social order" in the traditional, male-dominated "Muslim imaginary," states Tunisian psychoanalyst and women's rights activist Nādira Bin Ismā̄îl (Nédra Ben Smaïl), known as the founder of Tunisia's first women's refuge, Baytĩ ("My Home"), and as the author of a study analysing how increased premarital sexual activity has led to a renewed focus of the male gaze on female virginity ("Is she still a virgin? A real one? Or a fake one, broken and surgically fixed?”) (M.Ș.'; Y.N.) [ $\nearrow$ True vs. False]. Nādira presents her research at a podium debate on "The Feminine: identities and sexualities" during a colloquium held in Tunis to take stock of the fate of the "Arab Spring." There, she highlights the psycho-social tensions caused by accelerating change in actual sexual behaviour while cultural norms and to a large extent state policies still reflect a traditional moral code that restricts sexual relations to married heterosexual couples.

Male-female dynamics overall, not only sexual relations, are shaped in this interface between conservative value systems and changing practices and attitudes. Time and again, one finds people struggling with the pull of traditional norms, individual aspirations, moralist reactions, defiant rebellion, and social constraints. Both analytical voices and media testimonies clearly reflect this ambiguity and the tension between archetypal mental moulds and the variegated expressions of real-life actuality.

In primordial paradigm, it is the male gaze that defines 'woman' — a gaze, notably, that precedes seeing. "Close your eyes; look through your eyelids. Deep inside us, this is what a voice suggests us to do when faced with a woman's body." What you see is what you imagine: "Even when not undressed, a woman is always naked, she is "awra'- this Arabic term for what must be hidden is what defines 'woman.' [...] When you look at a woman, the creature that appears emerges somewhere between your eye and her body... She is the sacred, [...] she is the limit" demarcating the sphere of taboo (harām) and possible transgression. This is how Tunisian artist and writer Lilia BACHA characterises what she calls "the sinful gaze": the gaze typically directed at the female body.

Like the two Tunisian women, Egyptian philosophy professor Hasan HAMMĀD presents a sweeping critique of what he regards as a "male-dominated culture" (thaqāfa dhuküriyya). In his best-selling book Dawä̉ir al-tahrīm: al-sulța, al-ğasad, al-muqaddas ("Circles of Taboos: Authority, the Body, the Sacred"), he analyses the three big taboo areas that in many societies delimit what is deemed acceptable thought and practice: political power, sexual morality, and religion. In the author's view, these three taboos are intertwined; autocratic rulers and misogynist theologians work together to subject the body, through external coercion and internalised norms, to a regime ultimately serving one-man rule. Man, in this patriarchal socio-political order, represents reason; woman pure physicality that must be controlled by man — a system that Hasan HAMMĀD traces back to ancient religion and Greek philosophy. Anyone criticising any aspect of this system is quickly labelled an immoral, atheist rebel calling for chaos. Today, religious extremists and fundamentalists are the most vocal advocates of this line of thought, but beyond that, it remains deeply entrenched in

Journal of Arabic and Islamic Studies • 21 (2021) - Themed Section In2016: *319_*338 (C) Albrecht Hofheinz, Dept. of Culture Studies and Oriental Languages (IKOS), University of Oslo, NO 
society and in often unconscious structures of behaviour. "Therefore, to kill the father, symbolically, is a necessary precondition to break these circles of taboos," writes Hasan HAMMĀD, so that all human beings can achieve their rights, their freedom, their selfrealisation (AL-SHARĪF).

Whatever the concrete and complex social realities, these analysts attribute a decisive formative impact to the age-old archetypal polarity 'man is reason, woman is body and emotion; reason has to rule, for uncontrolled emotion is a threat to measured order.' Translated into social expectations, the fundamental idea is that a man must be strong to stand on his own feet, provide a home for a family, and protect himself and his kin against any threat; if he is unable to live up to this ideal, he quickly feels emasculated (as does the husband of the central character in the film Nawwāra) [ $\nearrow$ Young vs. Settled]. A woman's main task, on the other hand, is to take care of the home, and her noblest role is that of the mother of the heroic man who, the moment of his death in duty, embraces his mother in his mind. How powerful this idea remains is demonstrated in a statue erected in the city of Sōhāğ that seeks to portray the army protecting Mother Egypt through the image of a soldier clasping a woman. Then again, reactions to this statue show that at least the most rapacious aspect of the male gaze is up for criticism not only in academic circles: there is an outcry on social media as the statue evokes bitter memories of harassment and rape that many women have suffered at the hands of army soldiers and police officers (AL-BIDEYWI).

Such mistreatment of women is anathema to most, but underlying gender stereotypes stand strong in society and shape the way children are brought up, bodies are displayed, celebrities are advertised, work is distributed. Thus, the fashion industry transports a fairly conventional ideal of male and female beauty: men are typically physically strong and muscular, often sporting a cool, determined, defiant facial expression; women generally have a softer look, long wavy hair, and dark smoky eyes (CAIROSCENE TEAM [2]). At home and in school, boys and girls are formed to conform to traditional gender roles and are scolded for any deviation from the norm. A boy doing something as girlish as weaving is being yelled at in al-Nușūr al-șaghīra (Little Eagles); in Sheikh Jackson, a teenager must hide his fascination for the King of Pop's dancing from his father who is disgusted by such an effeminate creature (mukhannath) [ $\nearrow$ Dancing]. In the Tunisian city al-Hammāmāt, men wearing female clothing on their way to a Halloween party get beaten and locked up by police for "violating public decency." In Egypt, cross-dressing in public is unthinkable, and transvestites are repeatedly trapped and arrested even in private spaces (BACKHAUS; QUILLEN). Even a progressive pop band famous for their songs criticising the social and political status quo is not free from such stereotypes, although their lead singer later excuses himself for a line contrasting "real men" with those "putting on lipstick" (HofHEINZ 341; MAY AHMAD). Tunisian female rappers suffer from the macho attitudes that pervade hip hop culture-while other artists, such as Egyptian mahragānāt group Shobīk Lobīk in their most famous song "Māfish sāhib yitșāhib" ("No friend to befriend"), criticise the traditional association of masculinity with violent strength (DJILALi; FreEMUSE) [ $\nearrow$ Pop Music].

Just how firm a hold conventional ideas about gender have is apparent where the roles are turned around. The photo of a working-class woman dragging a heavy load past lazy young men wasting their time in a café goes viral on Twitter under the heading "Some girls in Egypt are tougher ( $a$ ğda) than 100 men” (ASHRAF 'ABD AL-ḤAMĪD; NŪR HĀNIM). Having

jaig • 21 (2021) - Themed Section In2016: *319_*338 
gained fame as the Fatât al- 'Araba, the "Handcart Girl," she is invited by President al-Sīsì to honour those who sacrifice themselves for the sake of their family and who thereby demonstrate that "hard work is the only magic key to solve all economic problems" (SAMĪKA; HUSAYN YŨSUF). Not only is the Handcart Girl celebrated as a model of the self-sacrificing woman, but by being presented as an out-of-the-ordinary case, she serves to confirm the general idea that it should be the man who provides for the family [ $\nearrow$ Young $v$ s. Settled] while the women first and foremost should take care of the home. This idea is tenacious; it runs through the discourse of many well-meaning men who, whether from an Islamic or a less religiously oriented persuasion, try to sing the praise of women. "In Islam, woman is a treasure," writes a pious commentator [ In Islam,...]. "In our tradition, She is the affectionate mother and the dedicated wife [...] As the Prophet said, 'Paradise lies under the feet of mothers"' (Didou Mohamed in BĀSIL NAWFAL). Without any need to refer to religious tradition, a relatively open-minded intellectual opens the film Hepta by saying "something along the lines of: 'We all need a tender woman to help endure life's blah blah blah.'" The film critic_MadaMasr's candid cartoonist ANDEEL_- dissects this mindset:

Despite thinking of itself as a good-intentioned delicate flirtation, this sentence carries inside it the seed of the problematic relationship between men and women the world over, when romantic relationships are seen in isolation (as they are in this film) from the unjust distribution of rights and privileges among men and women.

Women are, however, not only self-sacrificing mothers and spouses offering love and care. In man's mind, also the 'insatiable' woman looms large as a threat to man's abilities and man's authority. Women are beings that are difficult to understand and hard to argue with rationally since they are so emotional. Women arouse men physically and sexually and therefore disturb man's sobriety and focus. In marriage, women are constantly demanding attention and material support to the extent of draining man of his energy and power. Variations of this image can be found in many representations of male-female dynamics. ISLĀM ĞĀWĪSH's al-Waraqa, generally popular for its juvenile irreverence towards established ways of doing and perceiving things, often reflects a rather partial view of what women want. It sums up "the relationship in 3 lines": At the outset, the girl holds her fiancé's hands and makes him promise to never change. Next, a while into their marriage, she sternly demands: "You need to change." And finally, she turns away leaving her husband bewildered, her last words being, "I'm sorry, but you've changed." The satirical Facebook page "Diary of a crushed husband" (Yawmiyyāt Zawğ Mațhūn $)$ [ オInferiority = Superiority (Satire)] has attracted over a million followers for its posts that live on and strengthen the idea that in today's society, men's rights are more and more eroded and that they get walked over by women (RAHMA DIYĀ'). How can men defend themselves against these insatiable women? An Egyptian parliamentarian - an outlier perhaps, but one known for populist statements not mincing matters - justifies the necessity of female circumcision as follows: "Egypt's men suffer from sexual weakness, as is evident from the fact that Egypt is among the countries with the highest consumption of sexual stimulants. Only the weak take those. If we stop circumcising women, we need strong men, and we don't have men of that kind." So "for the sake of equality between men and women, women should be circumcised to reduce their sexual desire" (MUHAMMAD ȘUBḦI). "No!" a feminist retorts on TV:

jais • 21 (2021) - Themed Section In2016: *319-*338 
We must treat the men instead of butchering the women! Should every guy who has some sort of deficiency, mentally or culturally or physically, go and cut off a piece of a woman's body?? That way women will simply vanish. Instead of circumcising women, solve the problem by giving men free Viagra or sweetmeat sandwiches with cream!" (BASSĀM RAMAD̄ĀN).

This attempt at a sardonic critique of dominant stereotypes is met with vociferous protest, however. Quite a few comments accuse the feminist of vulgarity (?illit $a d a b$ ) and claim that female circumcision has been practiced in many cultures for thousands of years without causing any harm, that it is based on Prophetic Tradition, and that the country anyhow has bigger problems to solve. Despite longstanding official efforts to fight female genital mutilation (FGM), the practice remains firmly rooted in Egyptian customary culture. As around $60 \%$ of young girls are still affected, in defiance of a law prohibiting the practice, parliament in September increases prison terms for FGM from a few months to at least five years (ȘAFIYYA MuNĪR, "Mishraṭ").

Keeping the sexes apart is a fairly common solution to the troubles caused by uninhibited mingling. Schools in Egypt generally have gender-segregated classes; in Tunisia, boys and girls are often divided into separate rows. The Cairo metro runs women-only cars, and when a private regional railway company in the German province of Saxony introduces train compartments for women travelling alone or with children, Tunisian Islamist al-Șadà titles excitedly: "In a slap in the face to the extremist left elite in Tunisia and the Arab World, Germany applies the principle of gender segregation in trains" (SZ; AL-ȘADÀ). Social media users eagerly forward this headline, which appears to confirm that the superiority of 'Islamic' gender rules has now also been recognised in the West, thus giving it the added stamp of credibility by the technologically advanced world [ $\lambda$ Inferiority $v$ s. Superiority].

In real life, however, segregation of the sexes is threatened not only by "left elites;" it is being undermined (where it existed in the first place) by much more extensive economic and socio-cultural developments. It is against this background that Islamist movements endeavour to re-assert the notion that the male and the female must be shielded from each other. In their view, women are a huge temptation (fitna) for men, threatening men's commitment to focusing on piety and on leading a life according to the norms of religion. In a symbolic scene in Zahrat Halab / Fleur d'Alep, Islamist militants have young men practice shooting at naked female mannequin dummies. Everyday interaction demands that women must be veiled (for their pretty faces distract men), and the free mingling of the sexes must be reduced and regulated as much as possible. Dancing (as a form of mingling of the sexes that serves no other purpose than entertainment and sensual stimulation) is particularly dangerous; one must not engage in it and not watch it, not on YouTube and not in real life. Music, being conducive to dancing, is also dangerous (Sheikh Jackson) [ $\nearrow$ Dancing; $\nearrow$ Pop Music]. Through emphasising such rules, Islamic fundamentalist moralists try to uphold traditional gender norms against significant tendencies that work to erode them. People who do not conform to these standards must therefore not only watch out for society at large ("What will people think?" "What will the bawwāb [the 'gatekeeper' guarding access to buildings in Egypt's apartment blocks] think?” (CAIROSCENE TEAM [1]) [ $\nearrow$ The Honourable Citizen]. They are also being bothered by sometimes militantly aggressive moral custodians. In the documentary Nihāyāt sa ìda ("Happily Ever After"), a couple can be seen walking by

jais • 21 (2021) - Themed Section In2016: *319_*338 
the beach in Alexandria, against a backdrop of slogans written on the breakwaters that condemn illicit premarital relations. Somebody shouts at them, reprimanding them for hanging out together. "What can you do in a country where people don't even let you walk along the beach without getting molested?" the film asks. Cairo is "a city where police and society do not allow for a kiss by the Nile River, while turning their backs at the daily incidents of harassment," decries writer AHMAD NĀĞI this state of affairs, adding that desire-_rough and flaming, or still and quiet" - is always present, but acknowledging it and expressing it is strictly regularised and made taboo (harām). "This repressed desire creates a deep sense of dullness that reflects on experiencing the city and its current tragic moment."

Desire may be ever-present - but who has a right to desire? And what can, what should one desire? Sex? Love? Self-realisation? Young Tunisians interviewed by the pan-Arab daily al-Hayāt assert that young men primarily want a girl friend to satisfy their sexual desire, while women typically seek marriage "to escape society's disrespect for unmarried women" and hope to "find love, warmth, and protection in a man" (AL-'ASHIYY). In other words, traditional gender stereotypes still stand strong: Men want sex, women want love and protection. If society is to survive, with the family as its reproductive nucleus, these nonmatching desires need to be channelled and controlled. Men must be protected against temptation, and women against their own rapaciousness. However, this traditional imaginary is increasingly problematised, which is why "sexual harassment" (taharrush) has become a concept and is increasingly addressed as a problem, widespread on the streets and in the workplace, whereas before it used to be a taboo not talked about (NAJWA YOUNES). Traditional victim-blaming is still frequent; even a prominent, and glamorous, female TV presenter such as Rīhām Sa'īd thinks that "inappropriate clothing" may give a "man the impression that you're not a 'good girl"' and thus provoke harassment (EGYPTIAN STREETS). Such attitudes, dismissing as unnatural a woman's desire to move around naturally and unfold herself freely, seeking to contain and restrain her to curb temptation threatening men, are increasingly questioned, however, and society's often indifferent reaction is coming under attack and is slowly changing, as DĀLIYA 'ABD AL-HAMIID writes in Madà on 8 May, on the occasion of International Women's Day:

The revolutionary feminist movement in Egypt has been able to bring about positive change in people's knowledge and perceptions of sexual violence and sexual rights. One of the major achievements of the feminist movement is related to the issue of sexual violence against women in the public sphere. It is no longer out of the ordinary today for girls and women to report verbal and physical harassment to the police. They have also exposed and confronted police officers who refuse to file such reports. This was not the case 10 years ago.

Mediatized stories of more and more female survivors of sexual attacks who have overcome the hurdle of 'shame' traditionally preventing them from daring to speak out in public have "contributed to changing the mainstream victim-blaming attitude." Tellingly, in a high-profile paternity suit by actress Zeyna against prominent actor Ahmad 'Izz, the public is largely on Zeyna's side. Traditionally, out-of-wedlock pregnancies would have been a social disaster for the woman (DĀLIĀ 'ABD AL-HAMİD; MAY SHAMS AL-DĪN).

jais • 21 (2021) - Themed Section In2016: *319-*338 
New initiatives try to enlist and raise awareness not least among men, such as the Cairo campaign "Men and women together are fighting violence against women" that targets opinion leaders in local communities, schools, universities, and the media (ȘAFIYYA MUNĪr, "Ma'an"). Other campaigns focus specifically on sexual harassment and gender discrimination at the workplace (CBC; MAY SHAMS AL-DĪN; MUNÀ 'IZZAT). "Harassment is now a bad word that everyone fears inside corporates," activist groups such as Harassmap affirm. Commercial advertising responds promptly. Where five years ago, Carlsberg Group's "Birell" ran an ad saying "Grow your moustache and it will teach her manners" (Rabbi-l-hā 'l-shanab yi'allimha ' 'l-adab; HANI ELAGAMY), the new campaign is

tagged, 'Manhood is about good morals.' The series presents characteristics of a 'real man' as one who combats harassment and helps with household chores. This change definitely reflects a shift in the perceptions of the campaign's target audience, namely young men, regarding what is deemed to be acceptable male behavior. In other words, the advertising company had to replace their initial chauvinistic message-which correlated manhood with harassment-with an alternative motto that identifies combating harassment as an attribute of manhood. (DĀLIYÁ 'ABD AL-ḤAMĪD)

While activists report some success in their struggle to change people's view of the problem, it remains an uphill struggle both on the streets and inside the home. Statistics show that a third of married women in Egypt have been "subjected to physical, sexual or psychological violence at the hands of their husbands" (ȘAFIYYA MuNīR, "Ma'an"). Many victims still hesitate to take action as they face pressure from their families and reprisals from their employers. In Tunisia, where every other woman reports to have "suffered some form of street violence," a draft law increasing the punishments for sexual harassment, gender discrimination, and sexual intercourse with minors, again falls victim to haggling over the formation of a new government (BEN TAIEB [1]; WIKĀLAT TŪNIS; TARFA).

To increase the pace of change in the face of social and institutional impediments, activists and artists make their mark in popular media. The destructive aspects of patriarchal norms are taken up prominently in more than one Ramadan series this year, such as in alKhānka ("Mental Hospital") or Suqüt hurr ("Free Fall"). In al-Khānka, the female protagonist, fighting off harassment, turns into a dangerous being herself-just like in the Algerian short film Qindīl al-Bahr ("Medusa"), where a rape victim literally is transformed into a sea monster seeking revenge on men and on patriarchal society in general. In Suqūt hurr - apart from the main protagonist, a woman who had killed her husband-, we meet a woman who has been "forced by family and church representatives to stay with her abusive husband;" another one who "attempted suicide after her family refuse a marriage proposal from the man she loves;" and a third one who "was gang raped on a train." They all end up in a mental asylum. While the film critic lauds the focus on gendered violence and women's health, she thinks it is "frustrating when most depictions of mental health focus on women because this is already a stigma embedded in patriarchal society - that being irrational and mad is something that women do. This feminizes mental health, making it a women's issue when it isn't."

Gendered violence may impact male-female relations in important ways, but critical questions are being asked regarding the system that produces such a skewed situation.

jais • 21 (2021) - Themed Section In2016: *319_*338 
"Egyptian youth come to learn about sexuality primarily through pornography" as neither school nor parents provide much help (CHARBEL). Established morality discourages the free mingling of boys and girls from a young age and thus makes it difficult to learn to develop free and equal relations with the opposite sex, relations that regard the other as a person and a partner, relations where intimacy can grow out of mutual understanding. The sexual frustration that this system produces is frequently regarded as a prime reason for why men often look at women first and foremost as objects of sexual desire and treat them as such (HILLAUER). On the other hand, not only women but also many men are dissatisfied with this regimen and dream of the possibility of having a love-based relationship with a girlfriend even before marriage (most, however, admit that they would not marry a girl who is no longer a virgin). Many young people try their luck through Facebook and dedicated dating sites, but while some do find a suitable partner (NAJ), many others are disappointed when they discover that the polished virtual image they had been chatting with turns out less than perfect at the first off-line encounter.

However that may be, many unmarried couples do have sex before marriage. To do so they need to find a place; this is preferably arranged via a network of friends. People make insinuating remarks and tell jokes about how one "can" or "cannot," depending on access to such a "locality" (mukna in Egypt, "locale" in Tunisia) [ $\lambda_{P}$ Alsh]. Where a gratuitous place is not available, one needs to rent a furnished flat (shaqqa mafrūsha) for the purpose, often also shared between friends. Hotels, in particular mid-range ones, are not an option as they deny visits to guest rooms by non-family members of the opposite sex and generally do not rent out rooms to single women (and sometimes to single men) unless they produce "a letter from a family member or place of work or study to be her "sponsor." "Imagine what would happen if a girl is staying on her own and the devil plays with her head? Imagine a guy staying on his own, sees a family with a pretty girl and whistles at her?" ('AFīFİ)

In Tunisia, it is not illegal for an unmarried couple to be together, but still, social norms tend to stigmatise women who spend time with men other than their husbands as 'prostitutes.' The death of a young man who wanted to spare his girlfriend such a disgrace creates a stir on social media (RIHAB). He had invited her to his apartment but forgotten the key outside. When a neighbour locked the door to call the police, the young man tried to climb down the façade of the house to open the door from the outside but fell to his death. Commentators on social media are divided between disapproval of the girl and critique of a "retrograde" moral code that can have deadly consequences, a "hypocritical conservatism" where "everybody tries to demonstrate their good morality in order to hide their real immorality" (BOUZOUITA).

Sex workers - often driven into this profession out of a combination of child abuse and economic destitution - bear the brunt of the tension many men experience between their own desire and dominant social mores. In Tunis' only state-regulated brothel, workers note the "increasing disrespect younger men show to the women" (VASWANI). Customers out to obtain relief from their sexual frustration may project their anger at the frustrating conditions (the node of moral taboos in combination with the economic hurdles forcing them to postpone marriage) onto the prostitutes: "Sometimes I feel an overpowering desire to hit her. I feel as though she forced me into committing sin," a client in Egypt says ('UMAR SA'ĪD).

After all, it is love relationships what many-both men and women-dream of. Love stories are believed to be sure winners on the book market and on screen. The romantic

jais • 21 (2021) - Themed Section In2016: *319-*338 
comedy Laff wa-Dawarān (starring Dunyā Samīr Ghānim and Ahmad Ḥilmī [ $\lambda$ Celebrities]) is being leaked to millions on YouTube, denting the revenue of the blockbuster's producers (ADHAM 'ĀṬIF). Meanwhile, “Titanic - the Arabic version” (comedian SHĀDİ SURŪR's and Bushrà's satirical remake of the classic movie and the first Middle Eastern feature film professionally produced for YouTube) becomes an instant hit, reaching over a million viewers the first day alone (AL-BASHĀYIR). It seems the public realises that all-too crude clichés of romance are rather remote from their own lived reality [ 7 True $\nu s$. False]. When young author Walīd Dīdā decides to publish his amorous WhatsApp conversations with his fiancée Maryam Șaqr in book form, their romantic musings largely fall through with readers (AL-NIMR) [ 7 Social Media]. Instead of clichés, it seems that many young people are increasingly outspoken in their insistence to "discover their own feelings" (Jeanne d'Arc Mașriyya) and to determine themselves whom they want to spend their life with. They struggle with pre-ordained trajectories, stereotype roles, the secrecy hemming in emotions and passions, the double standards that such a life entails. A film such as Shaykh Jackson suggests a solution: to make room to trust one another. Societal expectations, however, still often prevent the full realisation of this dream, as is for example shown in the Tunisian film Nhibbik Hādi (Hédi) that shows a man who is attracted to an unconventional woman representing the promise of freedom and of finding oneself; in the end, however, he bows to established tradition.

Also $\pi$ Valentine's Day, the focus of much commercial and discursive attention, reflects not only the universal longing for tender love but opens up opportunities for posing critical questions regarding common male-female dynamics. A cartoon in al-Ahrām makes it appear as if men are inundated with female love to the extent that they wish this lovey-dovey romanticism would stop (AL-DīB). Social media, however, reveal another picture. On Twitter, the hashtag "ashān_il-bint_tihibbak" is trending to share tips for "how to make the girl love you" with those who spend Valentine's Day alone (SĀRA ȘALĀH). Buzzing is also the Facebook post "lehh batțalt ahibbak" where a 26-year old woman explains "why I stopped loving you": since their wedding three years ago, an imbalance has developed between the two spouses. While Mr. husband is "always sure that I love you to the extent of being a slave to this love for you," he himself is paying far less attention to her and her emotional needs:

I want to save my marriage. I don't give up easily. I tried, again and again, to make him change. I tried a million times, but nothing worked until [I wrote this Facebook post] the day before yesterday. That made him wake up and realise what he has done to me. Any man reading this should wake up and realise that his wife is his gem and not a piece of furniture!

There is nothing strange in that "my post was spread all over the web and [Facebook] groups," she explains. "After all, this is a common thing."-Subsequently, when the post spread "all over the internet," her husband gave her a box of chocolates the picture of which she published under the title "The idea succeeded!" (HIBA AL-MAHDİ [1], [2]).

Marriage remains the imagined final solution to the dynamics of male-female relations and the associated tribulations of young adulthood. Although this puts a burden of expectation on both young men and women, men may have legitimate goals much beyond establishing a family, while tradition regards marriage and childcare as a woman's main and 
foremost destiny [ $\lambda$ Young $\nu$ S. Settled]. A girl is under constant parental control until marriage; her family, and society at large, put a lot of pressure on her to abide by this expectation. In Mudhakkirāt Ğamīla Sa'ìd ("Memoirs of Ms Beautiful \& Happy"), DīnA IBRĀHIIM SHA 'BĀN (pp. 87-88) has her hero rebel against this pressure. "You're 30 already! Aren't we going to celebrate your wedding?" her mother prods. Or: "Congratulations on your exam results! Hope you're soon tying the knot!" "Marry!" is the standard solution to every problem. "You're upset? Marry! Nervous? Marry! Fatigued? Marry! Got a pimple? Marry! A slight cold? Marry!" The "spectre of spinsterhood" is hanging over every girl of marriageable age who doesn't accept the first promising suitor. "People start talking... you really must marry!!” "Arghhh! Enough! I'm not going to marry! Why can't you get that into your head? It's super easy! I'll only marry the person I love - and the one I love isn't going to marry me, so: I'm not going to marry!" The young girl insists that "this is $m y$ life, $m y$ life only! But the problem in Egypt is that your life belongs to all and everyone. It is they who decide on it as if it were their life. [...] They never leave you in peace!"

The traditional trajectory is thus being called into question at least by a section of young people. This is also obvious in films such as the documentaries Nihāyāt sa'ìda ("Happily Ever After") and Jeanne d'Arc Maşriyya ("Egyptian Jeanne d'Arc") that explore women's dreams to find themselves, to realise their own dreams, to cast off the shackles imposed on them by a patriarchal society, to rebel against their "inner enslavement." Tellingly, Jeanne d'Arc's central character, a bedouin girl who had fled to the city to become a dancer, fears her own tribe with its rigid social norms more than the military and the police who had tortured and raped her in jail. When and whom to marry, if and when to have children, these women want to decide for themselves. In "a society that imagines motherhood as a woman's only 'natural' path," they express the wish to have a choice, "to be able to command their bodies to make life, when and if they so pleased" (DİNĀ HúsAYN).

"Personal freedom" is also invoked by those who defend the veil, presenting it as a right that women should be free to choose. When the marketing research firm Sigma Conseil publishes an opinion poll suggesting that $93 \%$ of Tunisians are in favour of outlawing the full-face veil (niquab), the Islamist web site Essada.net launches a counter-campaign on Facebook ("Are you for permitting the niqā $b$ in Tunisia, considering it a matter of personal freedom?") that elicits many responses doubting the representativity of Sigma's poll. The comment that gathers most likes is, however, not using the 'freedom' argument:

Here's what a man has to say to this - and only real men will understand: If you're against the $n i q \bar{a} b$ and the $h i j \bar{a} b$, get out your wife and your sister in panties for us to see! The one who'll bad-mouth me for this is a cuckold... or a member of the Association Shams for gays... [ $7 \mathrm{LGBT}$ ]. If the cap fits, you wear it! A cuckold will not enter paradise. When God's Messenger was asked, 'Who is a cuckold?' he said, 'The one who is not jealous of his womenfolk (mahärimih)' (BADRO).

Such a blunt statement may, however, be regarded as a defensive reaction to what media describe as a growing tendency for young women to take off the veil they had been bearing previously (BĀSIL NAWFAL): "I don't understand why the hijāb should be obligatory," a 24year old justifies her decision. "Why should it be a problem if a girl makes a beautiful appearance? Men are also beautiful, and they don't wear a hijäb! [When I took it off,] I

زح่ • 21 (2021) - Themed Section In2016: *319_*338 
simply became... myself." Since this is a relatively new trend, turning around a decades-old development, it does not come smoothly. A woman in her thirties points out that "the chances for a girl to find a marriage partner are clearly decreasing if she is not veiled. This is even more so if she has taken off the veil since many Oriental men are scared of a girl who is able to make a decision of her own." While becoming less 'suitable' for marriage, women who take off the veil report being regarded as being more willing to enter into "free and unrestricted" relationships. "But give it some time, and Egyptian society will return to a more normal state of affairs where the hijā $b$ no longer is used as a measure to judge women." After all, society's view on veiling is not unified, and while a "narrow-minded" conservative attitude still dominates in places, women also tell of fiancés, male relatives and colleagues who share their view that the veil is not a religious obligation but a matter of personal choice. In Tunisia, it seems, women are even more frequently and openly declaring that "what women wear is none of your business" than what is the case in Egypt (SBOUI).

The principle of personal choice is also invoked when the 'burkini' becomes a focus of public attention. Some hotels in Tunisia forbid women wearing such full-body swimming garments to enter their pools, ostensibly for 'reasons of hygiene' - a decision criticised by the Tunisian Association for Supporting Minorities, an organisation that has made a name for itself for most outspokenly denouncing all forms of discrimination, be they religious, racial, sexual, physical, or cultural. "Wearing a burkini or a bikini is a personal choice," the association declares (BEN TAIEB [2]). And when the news spreads that French officers have started to fine women for wearing burkinis at the beach, social media expose the irony of public authorities stripping women of their liberties-in the name of freedom just as in the name of religion. Celebrated cartoonist Khālid al-Bayh juxtaposes the image of two French policemen asking a woman to uncover herself with that of two of their Saudi counterparts asking a woman to cover up (KHALIDALBAIH). The image goes viral, and users add further pictures of women in the West being policed, not so long ago, for wearing too revealing clothing at the beach (GONZO).

Some young women (mostly from an upper-middle-class background) take their wish for self-determination to a new 'extreme': they want to live by themselves. "The issue of women's rights is no longer only one of legal problems. Nowadays, some are calling for women's independence from their families, in search of 'freedom,' as they say" (DĪNÁ 'ABD AL-KHĀLIQ). "Women today are fighting for their financial independence, and for their right to live outside their family homes" (DĀLIYĀ 'ABD AL-ḦAMİD) (Mada). "'Eysh-beythurriyya" ("Bread - a home-freedom") is FEMI-HUB's version of the revolutionary slogan "Bread-Freedom-Social Justice" of 2011. The organisation tries to help unmarried girls to find work and a place to live. Calling themselves mustaqillät, "independents," these girls are willing to face considerable social adversity and to be called harlots and sluts (FEMIHUB). "Arab societies do not allow a girl to be an independent person, standing on her own feet economically and living by herself," a girl in her twenties sums up the reasons for why it is almost unimaginable for an unmarried girl to move out of her family's home. Such an idea "is all but impossible to carry out in practice and to see through since it is completely unacceptable to the family" (DİNĀ 'ABD AL-KHĀLIQ). Society tends to suspect that any girl living by herself is a potential prostitute (HUFFPOST TUNISIE), and families, eager to protect their reputation, will go a long way to thwart any such attempt to 'break free': moral pressure,

jais • 21 (2021) - Themed Section In2016: *319_*338 
physical constriction, asking employers to dismiss the recalcitrant girl. Horror stories are told as a warning: "Remember the case of the daughter of Layla Ghufrān the singer?" When she moved from home to share an apartment with another girl, "their so-called independence made them easy prey for thieves and criminals, and they paid with their lives." Therefore, another young woman concludes, this idea of living by yourself "may appear as a way out to a girl going through a difficult time, but she will soon realise how mistaken she was ( $\mathrm{sa}$ tudrik madà s $\vec{u} i h \bar{a})[\ldots]$, come to her senses, and return to the family fold" and the protection of her male relatives. "Independence doesn't necessarily mean to leave your family. A girl needs to develop her independent personality even within her family". A (female) professor of psychology at the Egyptian National Center for Social and Criminological Research concurs:

Girls moving out from their families, that's bound to undermine the idea of the family and cause chaos in society. It's fully possible for girls to enjoy an independence of culture and thought within their family home. This idea will not succeed in our society since it conflicts with many of our traditions and customs and religious norms. (DİNĀ 'ABD AL-KHĀLIQQ)

Such adamant defence of social customs and religious norms appears to indicate, however, that the 'traditional' family home does feel threatened by such calls for girls' "independence" and no longer is as stable as its custodians would like it to be. The divorce rate in Egypt has risen to $40 \%$, the highest in the world according to UN statistics, claims a report by the Cabinet's Information and Decision Support Center ('ABD AL-NĀṢIR SALĀMA; MAHMŪD BAKRİ). Facebook and WhatsApp are often blamed for this: they make it much easier both to enter into and maintain extramarital relationships. "The percentage of women cheating on their husbands is now almost half that of men cheating on their wives," claims the admin of the Yawmiyyāt Zawğ Mathūn Facebook page-a statement for which he is dragged to court for "contempt of the women of Egypt" (ihānat sayyidāt Mișr) (AȘWĀT MAȘRIYYA; SHARİF ABŪ 'L-FAḌL). Social media also make it easier to discover marital infidelity - and according to psychologists, it is much more frequent for the wife to come across incriminating evidence against her husband than the other way around, which reportedly leads to a huge rise in the number of women seeking a divorce in court $\left(\mathrm{khul}^{\circ}\right)$ [ $\lambda$ Court Trials; $\lambda$ Social Media]. "Spinster" ('ānis) and "divorcee" (mutallaqa) are still used as an insult (MAHMMŪD BAKRĨ), but as divorced women become more common, society's view of them grows more lenient, which in turn makes it easier for women to take the initiative in seeking a divorce. Other factors play a role, too: in addition to reasons acceptable traditionally — childlessness, for example - many marriages do not survive the first year since husband and wife find out that they do not go well together-an expectation that a couple increasingly has of each other. The phenomenon of premarital affairs also nurtures distrust, which can ruin a relationship.

Cultural production reflects this trend. 'Ayzza attaliq ("I [fem.] Want a Divorce"), a new collection of short stories "based in real life" arouses interest at the Cairo book fair; its title deliberately challenges the best-selling blog-turned-novel-turned-TV-series 'Āyza atğawwiz ("I [fem.] Want to Marry") of the late 2000s (DU'Â' HiLMĪ; MAȘR AL-'ARABIYYA; GHĀDA 'ABD AL-'ÁL). And in one of the year's big hits on YouTube, Moroccan-Egyptian pop star

jais • 21 (2021) - Themed Section In2016: *319-*338 
Samīra Sa ${ }^{c} i d$ does away with old stereotypes of divorced women as pitiable creatures befallen by disaster:

"See? I left him, and nothing's happened," she sings in "Māhașalsh ḥāga." "I'm still eating, laughing, working... doing everything. I'm not at all distressed or depressed. I don't clasp his picture and feel miserable like an idiot. [...] On the contrary, I feel at ease and happy. It turned out to be not such a bad thing after all to live alone. I'll start my life with a clean white page.

And in a sideswipe at her ex, she exclaims: "I know he's going around now telling people what a mean and wicked girl I am: 'Look what she's done to me!' Oh, I can smell your lies from afar!" (SAMĪRA SA'İD). "This song," one of the top comments reads, "should be the anthem of all divorced women and all free minds!" Another one adds, "Had it not been for this song, I'd still be at the mercy of the treacherous guy I used to really love. It made me strong after I had thought I couldn't live without him and without hearing his voice."

Still, there are many who have misgivings about the growing tendency for women to initiate divorce (MAHMMŪD BAKRĪ): Why is the divorce rate so low in China? Because women there still understand that "a wife's duty is to take care of her husband and her parents." But here?

Look at what they have managed to bring about!! A woman has no right to rise up against her man, for God has said, 'Men are the managers of women' [Q 4:34]. A woman must not interfere in her husband's privacy and private affairs since she could cause damage to his private interests, both security-wise and politically. But unfortunately, our society has lost its mind [...] Man is belittled in the eyes of most wives; this pushes women to file for divorce, due to Suzy Mubārak's law [disparagingly called thus after deposed President Mubārak's wife who had headed a reform to the Personal Status Law making it easier for women to seek divorce]. And this has destroyed a large section of society.

Nowadays, another man chimes in, women "believe that these unfair laws provide them with power and with a knife to put at men's necks and help them to rebel against their husbands. And when the man gets fed up with this rebellion (nushīz), she resorts to protracted $\lambda$ Court Trials and [...] to file for divorce $\left(\mathrm{khul}^{\mathrm{l}}\right)$. "-“"Wifely rebellion'?!?," a woman retorts:

This is utter nonsense! Divorce is a right God has given to both husband and wife if one of them cheats on the other or if they otherwise fear that continuing in wedlock will make them unfaithful to the precepts of religion. [...] What do you mean-if a woman finds out that her husband is a lecher, should she leave him to mess around with honest girls? If she believes he's unfaithful, should she not try to find proof that would justify her separation from him and put an end to him hurting her? And what 'security and political interests' are you talking about, you retarded imbecile?? What you mean are 'physical' interests and mental sickness, you mean instincts and desires and moral degeneracy! Take your rotten Wahhābī thinking and get lost!

jais • 21 (2021) - Themed Section In2016: *319_*338 
The men thus lashed out at bang back, however; a commentator in the same thread claims that

one of the most important reasons for divorce [...] is that many women no longer are circumcised. And that alone, by the way, is reason enough for divorce... it's like the man feels he's sleeping with Ahmad 'Adawiyya [an elderly star of raucous pop music]... Yuck! Just imagine, you reach out and find this guy waiting for you down there...!

At the legal level, reformists and conservatives in Egypt struggle over a proposed revision of the Personal Status Law that would split assets acquired by husband or wife during their marriage equally in case of divorce, in line with international trends. While some religious scholars support this suggestion, it is opposed by others since it "would eliminate the "familyfriendly nature' of Middle Eastern society, transforming Egyptian family life into a materialistic replica of Western families." A "proper marriage contract in Islam specifies the woman's rights, including the right to have custody of the children and obliging the father to support them," they argue [ In Inlam, ... ]. Reformists demur: "religious men must realize society has changed [...] there are now women who work outside the home and serve as breadwinners for the family, men who abandon their families without providing support and women who face ongoing domestic violence because they have nowhere to go if they leave their husbands" (HIDJI [1]).

The struggle for equality, in legal rights and social practice, is being led on many fronts. Old ideas, and the power of the male gaze, are powerfully entrenched but are also being vociferously challenged. The old notion that parents wish for male children more than for girls still stands strong enough to be effective in a cartoon showing a pregnant woman who has just been told by her doctor that she will give birth to a girl. In her despair, she calls upon the police for help: "Give him a proper beating, so he'll tell me it's a boy!" ('ABD ALLĀH) [ $\nearrow$ The Policeman Criminal; $\nearrow$ True vs. False]. When eight female presenters are suspended by Egyptian State TV for being obese and given a month to achieve "a decent appearance," rights activists protest: "We've yet to hear about a male presenter being relieved of his job for being overweight" (HIDJI [2]). Many men, these activists claim, still regard women as inferior when it comes to public functions; they recall that the state, for example, has never entrusted women with what they call "sovereign ministries," only with soft ones such as environment or social solidarity. Tunisia has often portrayed itself as having come further than its neighbours regarding women's rights. Thanks to a legal quota, $35 \%$ of the members of parliament there are women-more than anywhere else in the Arab world (' ${ }^{c}$ M.). This year, the country congratulates itself on the appointment of the first woman as a high-ranking security officer at the national level (AL-'ARABĪ AL-JADĪD; RT ARABIC). Still, the unemployment rate for women $(40 \%)$ is twice as high as that for men in Tunisia (AL$\left.\mathrm{SA}^{\mathrm{C}} \overline{\mathrm{I}} \mathrm{D} \overline{\mathrm{A} N} \overline{\mathrm{I}}\right)$. Therefore, while celebrating the sixtieth anniversary of the 1956 Personal Status Law that was revolutionary in its time, Tunisian women warn that full gender equality is far from achieved (RFI). The law still regards the husband as the head of the family, while in neighbouring Algeria and Morocco, the couple is now conceived of as a pair of equal partners. Equality in inheritance is also a goal that remains to be achieved; a draft law is being debated in parliament but faces considerable resistance from conservative Islamists. Women

jais • 21 (2021) - Themed Section In2016: *319-*338 
also criticise that parenting and domestic chores are largely left to them: "You just have to walk past the cafés to see how many men are hanging out there, while women often only go out for shopping, and are lining up at the bus stops early in the morning to go to work" (KEFI).

While activists fight against continuing forms of discrimination, many researchers also note that profound changes are in fact underway and that power relations between the sexes are being questioned and reconstructed. Control over women's bodies, these analysts argue, is patriarchy's last bastion; it is precisely because the patriarchal system faces significant challenges that the struggle over who has the right to control a woman's body at present is particularly acute (BELHADJ).

In Ramadan - traditionally a month for awareness-raising - an Egyptian TV campaign backed by the National Council for Women, the UN and various other international donors airs a series of videos aiming to reach an audience as large as possible with the message that women are not inherently weaker than men. Through depicting women defying common daily challenges, the Taa Marbouta campaign "changes the rhetoric and addresses microagressions, the implications of gender roles, and showcases the social constructs and how they affect women's psyche, and limit their potential and ability to dream big and actualise those dreams" (CAIROSCENE TEAM [3]). The most widely shared product of the campaign (hashtagged \#Sirr_quwwitik "The secret of your (f.) strength") is released on YouTube a few months later. Rap icon ZĀP THARWAT and emerging film star Amīna Khalīl [ $\nearrow$ Celebrities; $\nearrow$ Pop Music] join forces to tell the story of Nūr, a mechanical engineer who bends over backwards to become a successful professional. Impressed with the resume Nūr has submitted, a middle-aged employer is surprised to find out that the person arriving for the job interview is a woman ('Nūr' is a gender-neutral name). "Should I hire a girl? Can she be a boss respected by the other workers?" But he turns around and blames himself for his antiquated stereotypes: "I owe her an apology for just the thought!" "'His' role will never be complete without 'Her' role," Amīna concludes this attempt to advance Egyptians' recognition of the advantages of gender equality (CAIROSCENE TEAM [4]).

Will this message fall on fertile ground? Is the glass half-full or half-empty? The Arab Youth Survey 2016 reports that "[r]egardless of gender, two in three young Arabs believe their leaders should do more to advance the rights and personal freedom of women" (ASDA'A Burson-MArsteller). The leaders? When "Egypt's state-affiliated National Council for Women [the same one that is behind the Taa Marbouta campaign] is calling on President Abdel Fattah el-Sisi to name 2017 'the year of the woman,' after having dubbed 2016 'the year of the youth' [... s] ocial media users joke that this can only be an omen" [MEE CORRESPONDENT].

\author{
Related Entries \\ ARRAYs - PAlsh $\downarrow$ Celebrities $\downarrow$ Court Trials $\downarrow$ Dancing $\downarrow$ In Islam, ... LGBT $\downarrow$ The Policeman \\ Criminal Pop Music $\diamond$ Social Media $\downarrow$ Valentine's Day \\ CODES - Freedom vs. Constraint $\downarrow$ Inferiority vs. Superiority $\downarrow$ True $v s$. False $\downarrow$ Young vs. Settled \\ CODES COLLAPSED - Inferiority $=$ Superiority $($ Satire $)$
}

jaig • 21 (2021) - Themed Section In2016: *319_*338 


\section{References}

\section{Written Sources and Videos}

'ABD AllāH. "I'tidā' umanā' al-shurța 'alà al-ațibbā'." al-Maṣrī al-Yawm, February 12, 2016, <https:// www.almasryalyoum.com/caricatures/details/10154>.

'ABd AL-NĀṣin SALĀMA. "al-Ṭalāq... Miṣr al-ūlà 'ālamiyyan.” al-Maṣrī al-Yawm, April 20, 2016, $<$ https://www.almasryalyoum.com/news/details/933463>.

ADHAM 'ĀṬIF. “Tasrīb fîlm 'Laff wa-dawarān' li-'Aḥmad Ḥilmī’ 'alà 'Yūtyūb'.” Vetogate, September

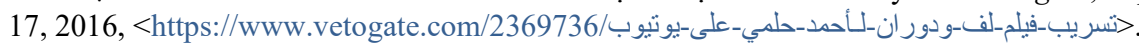

‘.M.. “al-Nisā’ sa-yumatthilna 35 bi’l-mi’a fī majlis nuwwāb al-shacb.” Kapitalis, August 25, 2016,

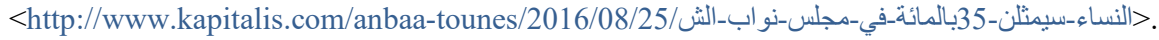

'AFī̄Ī, Hiba. "Lā nisāè fì fanādiq hādhihi 'l-madīna." Madà, August 26, 2016, <https://madamasr.

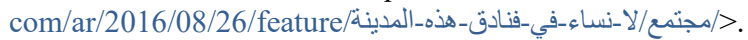

AḤMAD NĀǦīi. "Haythiyyāt hụum barā’at riwāyat 'Istikhdām al-ḥayāt': \#ḍidd muhākamat_al-khayāl." Wassi c khayālak, February 16, 2016, <http://archive.li/gQHQm>.

AHMED NAJI. "Farewell to the youth." Madà, January 2, 2016, <https://madamasr.com/en/2016/ 01/02/opinion/u/farewell-to-the-youth>.

ANDEEL. "Hepta: Do you need to learn how to love?" Mada, April 29, 2016, <https://madamasr.com/ en/2016/04/29/feature/culture/hepta-do-you-need-to-learn-how-to-love>.

[al-'ARABĪ al-JADĪD =] N. N. "Tūnis: Ta'yīn awwal imra’a mudīra amniyya bi-wizārat al-dākhiliyya."

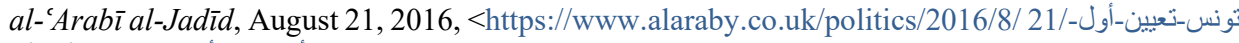
ا امر أة-مديرة-أمنية-بوز ارة-الداخلية.

[ASDA'A BURSON-MARSTELLER =] N. N. Arab Youth Survey 2016: Inside the hearts and minds of Arab youth. [Dubai]: ASDA'A Burson-Marsteller, 2016, <http://www.arabyouthsurvey.com/ pdf/whitepaper/en/2016-AYS-White-Paper.pdfs.

al-`AsHIYY, Khawla. "Tūnisiyyūn yashkūn: al-'alāqāt al-elektrōniyya maghshūsha." al-Hayāt, Nov. 21, 2016, <https://www.evernote.com/1/AmQo8vqno_hDFIjZukQ57 cvjXm9Bk7aJsYI>.

ASHRAF 'ABD AL-ḤAMīD. "Ṣūratān li-fatātayn tahuzzān mawāqi' al-tawāṣul fĩ Miṣr." al-'Arabiyya,

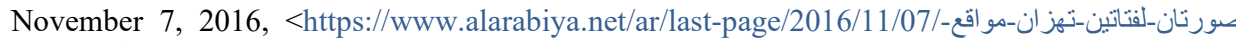
.html>.

[AȘWĀT MAȘRIYYA =] N. N. "al-Nā’ib al-āmm ya’mur bi-ḍabṭ wa-iḥ̣ār Taymūr al-Subkī bi-tuhmat 'ihānat sayyidāt Mișr'." Așwāt Mașriyya, February 16, 2016, <https://web.archive.org/web /20160220101811/http://aswatmasriya.com/news/view.aspx?id=02b2c1b2-fed9-49fa-8d0ddfab18fbd1e9>.

BACHA, Lilia, Le regard en péché : réflexion sur le regard porté sur le corps féminin, Paris : Harmattan, 2015.

BACHA, Lilia \& Ghaleb BENCHEIKH, «Le regard en péché », émission « Cultures d'islam », Radio France Culture, January 31, 2016, <https://www.franceculture.fr/emissions/cultures-dislam/leregard-en-peche>.

BACKhaus, Andrea, „Ägypten: Der Polizeistaat ist zurück,“ Die Zeit, September 28, 2016, <https:/ www.zeit.de/politik/ausland/2016-12/aegypten-militaer-polizeistaat-revolution-rueckblick/ komplettansicht>.

BADRO, Magnom. "K'lām r'jāl w-mā yifhamū kān 'l-rājil” [comment on “\#Istiftā'-al-Șadà net”], Mawqi al-Sadà al-Ṣaf̣a al-Rasmiyya, Facebook, March 25, 2016, <https://www.evernote.com/l/ AmR9pqy2r2FKDK38LOX6U811i2SySUrq1A4>.

jحis • 21 (2021) - Themed Section In2016: *319_*338 
[al-BASHĀYIR =] N. N. "Taitānīc al-'arabī yuḥaqqiq milyūn mushāhada khilāl awwal ayyām 'arḍihi 'alà 'l-internet... shāhid al-fîlm." al-Bashāyir, September 13, 2016, <https://www.evernote.com/ 1/AmS5BR9dZexJgawJise8XHZcELCKoM9Rahc>.

BĀSIL NAWfAL. "Li-mādhā izdādat zāhirat khal' al-hijāāb fī Mișr?” Rașîff2, April 2, 2016, <https:// raseef22.com/article/53328-لماذ|ازدادت_ظاهرة-خلع_الحجاب_في-مصر؟); comments archived at <https:// www.evernote.com/1/AmRPTtyg3M5FarT3fsBETWPyaMbr9vNgAys>.

BASSĀM RAMAḌ̄N. "Nāshița nisā̄iyya: 'Badal mā tikhtinū 'l-banāt aṣrifū li'l-riğğāla viāğrā wi-ḥalāwa bi'l-Pishța'." al-Mașrī al-Yawm, September 9, 2016, <https://www.evernote.com/ 1/ AmTeFOMEeOdByYsHV7ipWaB-gH-SSacJ3Z4>.

BELHADJ, Ahlem, presentation to the session « Le féminin : identités et sexualités », conference on Les "printemps arabes » entre effacement et inscription. Regards croisés franco-tunisiens entre psychanalystes, artistes et chercheurs en sciences sociales. Tunis : Revue Passage \& Comité Freud, April 24, 2016, <https://www.evernote.com/1/AmSJMMFNbP9J1K6Xn_qze7VqIIo UuXdIGoY>.

BEN SMAïL, Nédra, Vierges? la nouvelle sexualité des tunisiennes. Tunis : cérès, 2012.

BEN TAIEB, Zaineb [1]. "Government minister : Half of all Tunisian women subjected to public violence.” Tunisia Live, August 4, 2016, <https://web.archive.org/web/20160805183654/http:// www.tunisia-live.net/2016/08/04/government-minister-half-of-all-tunisian-women-subjected-topublic-violence>.

Ben TAIEB, Zaineb [2]. "Hotels in Tunisia Prohibit Burkinis on Grounds of 'Hygiene, " Tunisia Live, August 25, 2016, <https://web.archive.org/web/20171102094440/http://www.tunisia-live.net:80/ 2016/08/25/hotels-in-tunisia-prohibit-burkinis-on-grounds-of-hygiene>.

AL-BIDEYwī, Muḥsin. "Mușammim timthāl 'Umm al-Bațal' al-mushawwah bi-Sōhāğ: 'Ha-'addiloh wiha-yibPà tamām'." al-Yawm al-Sābic, September 3, 2016, <https://www.youm7.com/story/

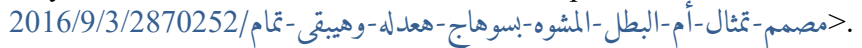

Bouzouita, Kerim, « Notre société tunisienne est rétrograde », Facebook, August 1, 2016, <https:// www.facebook.com/kerimbouzouita/posts/10154988818944041>.

[CAiroScene TEAm, $1=$ ] N. N. "15 Egyptian girl problems you can probably relate to." CairoScene, April 2, 2016, <https://www.cairoscene.com/LifeStyle/15-Egyptian-Girl-Problems-You-CanProbably-Relate-To>.

[CAiroScene TeAm, $2=$ ] N. N. "21 of Egypt's models to watch for on Instagram in 2016", CairoScene, May 26, 2016, <https://www.cairoscene.com/LifeStyle/21-of-Egypt-s-Models-To-Watch-For-OnInstagram-In-2016>.

[CAiroScene Team, 3 =] N. N. "Taa Marbouta: A 360 approach to women's rights advocacy." CairoScene, July 30, 2016, <https://cairoscene.com/ArtsAndCulture/Taa-Marbouta-A-360-Approach-toWomen-s-Rights-Advocacy>.

[CAiroScene Team, 4 =] N. N. "Video: Zap Tharwat and Amina Khalil's chilling new song on life in Egypt." CairoScene, November 26, 2016, <https:/cairoscene.com/Buzz/VIDEO-Zap-Tharwatand-Amina-Khalil-s-Chilling-New-Song-on-Life-in-Egypt>.

$[\mathrm{CBC}=]$ N. N. ““Aswira elektrōniyya tusağğil al-ṣawt' ... aḥdath țuruq al-ḥadd min al-taharrush alğinsī." $C B C$, November 15, 2016, <https://www.evernote.com/1/AmTA8Z_xPp9FwaNuqbjWew Ut8KuynTymECg>.

Charbel, Juno. "Egypt's shady world of sex videos." Madà, March 11, 2016, <https://madamasr. com/en/2016/03/11/feature/society/egypts-shady-world-of-sex-videos/>.

DĀLIYĀ 'ABD AL-ḤAMĪD. "Lā tashbah al-laylatu al-bārihāata : 'an taghayyur manẓūmat al-qiyam almuğtama'iyya al-mutacalliqa bi-ḥuqūq al-nisā’" | "For the women of Egypt, today is not like

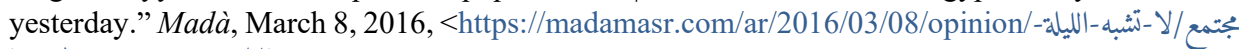

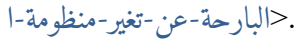

jais 21 (2021) - Themed Section In2016: *319_*338 
al-DīB, Anas. “Arğūkī yā ḥabībtī kifāya Valāntain.” al-Ahrām, February 16, 2016, <https://is.gd/ 4SFpRr>.

DĪNĀ ‘ABD AL-KHĀLIQ. ““Femi-Hub’ hāribāt min al-ahl bi’sm al-ḥurriyya.” al-Wațan, January 1, 2016, $<$ https://www.elwatannews.com/news/details/891202>.

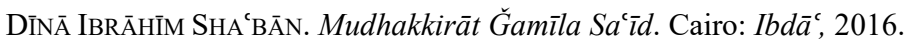

DīnĀ ḤusAYN. "Ikhtiyār al-umūma." MadàMaṣr, March 21, 2016, <https://madamasr.com/ar/2016/ 03/21/feature/lifestyle/اختيار-الأمومة>

DJILALI, Emma. "Women in hip hop: Making space for Tunisia's unseen queens.” August 17, 2016, $<$ https://www.middleeasteye.net/features/women-hip-hop-making-space-tunisias-unseen-queens>.

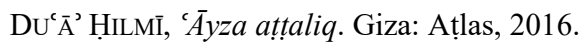

[EGYPTIAN STREETS =] N. N. "Riham Saeed sentenced to prison for airing private photographs of a sexual harassment victim." Egyptian Streets, February 29, 2016, <https://egyptianstreets.com/ 2016/02/29/riham-saeed-sentenced-to-prison-for-airing-private-photographs-of-a-sexualharassment-victim>.

FEMI-HuB, Facebook group, <https://www.facebook.com/Femi-Hub-780813025375003>.

[Femi-Hub =] N. N. "Masā masā.” Facebook, March 25, 2016, <https://fb.com/story.php?story_ fbid $=832314643558174 \&$ id $=780813025375003>$.

[FreEmuSE $=$ ] N. N. "Egypt: Mahraganat artists challenge limits." Freemuse, February 23, 2016, $<$ https://freemuse.org/news/egypt-mahraganat-artists-challenge-limits $>$.

GHĀDA 'ABD AL-'ĀL, 'Āyza atğawwiz. Cairo: Dār al-Shurūq, 2008.

Gonzo, [no title]. "seenthis”, August 24, 2016, <https://seenthis.net/messages/518492>.

HANI ELAGAMY. "I'lān Bīrēll - Hạzza — Rabbī-1-hā 'l-shanab yi allimhā 'l-adab gp3." YouTube, August 30, 2011, <https://youtu.be/Nx14arUfv-4>.

ḤASAn ḤAMMĀD, Dawā̉ir al-tahrīm: al-sulța, al-ğasad, al-muqaddas. Cairo: Dār Miṣr al-`Arabiyya, 2016.

HiBa AL-MAHDī [1]. "Ṣuwar | Aghrab hadiyyat Falāntain... Lēh batțalt ahibbak.” DōtMaṣr, February 16, 2016, <https://www.evernote.com/1/AmSAv1bQ-dhAma1 fizjkHv9Mc-jFxNyZz1Q>.

HiBA AL-MAHDī [2]. "Șuwar| Radd fíl zawğ șāḥibat rasā’il 'Lēh baț̣alt ahịbak'.” DōtMaṣr, Feb. 16, 2016, <https://www.evernote.com/1/AmQuUgrb1aNL6J-SFH7Gq3BtzaifG3A-WLA>.

HIDJI, Ahmed [1]. "Egypt's divorced women demand their fair share of assets." al-Monitor, September 18, 1016, <https://www.al-monitor.com/pulse/originals/2016/09/egypt-divorce-laws-womenrights-societal-change.html>.

HIDJI, Ahmed [2]. "Egypt's state TV under fire after suspending anchorwomen until they shed pounds." al-Monitor, August 19, 1016, <https://www.al-monitor.com/pulse/originals/2016/08/ egyptfemale-tv-presenters-suspended-overweight-controversy.html>.

Hillauer, Rebecca. „Sexuelle Frustration junger Muslime.“ Deutschlandfunk Kultur, April 11, 2016, $<$ https://www.deutschlandfunkkultur.de/muslimische-gesellschaft-sexuelle-frustration-jungermuslime.976.de.html?dram:article_id=350994>.

HofHeINZ, Albrecht. “\#Sisi_vs_Youth: Who has a voice in Egypt?” Journal of Arabic and Islamic Studies, 16 (2016): 327-348.

[HufFPost Tunisie =] N. N. "Tunisie-Affaire Amina Sboui: 'Des orgies sont organisées à Sidi Bou Saïd et personne ne s'en offusque!'” HuffPost Tunisie, Oct. 14, 2016, <https://web.archive.org/ web/20161015012454/https:/www.huffpostmaghreb.com/2016/10/14/tunisie-amina-sboui-sidi-_n _12486576.html>.

ḤUSAYN YUSUF. “'Ṣūra' khayrun min alf kitāb... al-Ra'̄̄s yaftaḥ bāb sayyāratihi bi-nafsihi li-muwāṭina miṣriyya... Munà al-Sayyid a'lanat sha’an al-'amal fa-a'là al-Ra'̄iss sha'nahā... al-Ra'îs yudrik anna

jais • 21 (2021) - Themed Section In2016: *319-*338 
al-‘amal miftāḥ al-khurūj min al-ḍāàiqa al-iqtișādiyya fa-kānat risālatuhu li'l-mișriyyīn.” al-Yawm

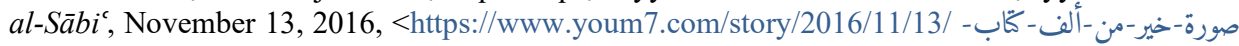
الأئيس-يفتح-باب-السيارة-بنفسه/2966188.

IsLĀM ĞĀWīsh. "al-'Alāqa fī 3 suṭūro,, al-Waraqa, December 30, 2016, <https://fb.com/Gawish. Elwarka/photos/a.112485845441785/1777707815586238/?type=1\&theater>.

KefI, Chiraz. «Tunisie : 60 ans après, une relecture critique du CSP s'impose. » GnetNews, August 12, 2016, <https://news.gnet.tn/archives/temps-fort/tunisie-60-ans-apres-une-relecture-critique-du-cspsimpose/id-menu-325.html>.

KHALIDAlBAiH. “\#Khartoon - Laws - To cover or uncover?” Khartoon! by KhalidAlbaih, Facebook, August 24, 2016, <https://fb.com/KhalidAlbaih/photos/a.234762049873663/ 1476060055743850>.

M.Ṣ.... "50 bi'l-mi’a min al-Tūnisiyyāt aqamna 'alāqāt jinsiyya khārij ițār al-zawāj.” Kapitalis, August

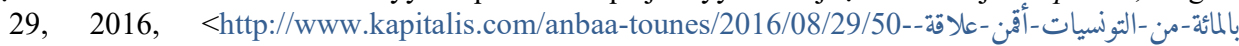
جنسية>

MAḤMŪD BAKRĪ. "Mișr al-ūlà 'ālamiyyan fì hạalāt al-țalāq." RTOnline, December 6, 2016, <https://

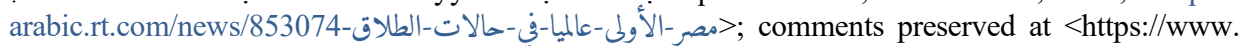
evernote.com/1/AmR6kFuoioBDf7zBsH_bbzz0HvkFpzeVYLy8>.

[MAṢR AL-'ARABIYYA =] N. N. “'An kitāb 'Āyza ațtaliq... Fatayāt: 'Iḥna mish ha-nitğawwiz aṣlan'.' Mașr al-'Arabiyya, February 11, 2017, <https://youtu.be/QofUDz5TS5Y>.

MAY AḤMAD. "Fīdēō... aḥad a'ḍā' 'Cāirōkee' ya tadhir 'an 'Hutṭ ạ̣mar shafāyif' fì ughniyatihim alakhīra: mumkin titfihim taqlīl min il-mar’a...āsif.” al-Bidāya, March 13, 2016, <http://albedaiah. com/news/2016/03/13/108856>.

MAY SHAMS AL-Dīn. "Ḥikāyāt al-taḥarrush al-ğinsī al-maskūt 'anhu fī 'l-mu’assasāt al-ṣaḥafiyya" "Untold stories of sexual harassment in Egyptian newsrooms." MadàMașr, August 23, 2016,

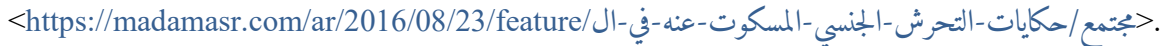

[MEE CORRESPONDENT =] N. N.. "Need baby milk? You'll need a breast exam first, says Egyptian health ministry." Middle East Eye, September 12, 2016, <https://www.middleeasteye.net/ features/need-baby-milk-youll-need-breast-exam-first-says-egyptian-health-ministry>.

MuHammad ȘubḤī. "Riggālit Maṣr 'andahā ḍưf ginsī... Ilhāmī ‘Agība: lāzim il-sittāt tirḍà bi'l-khitān 'alashān il-'agala timshī.” Barlamān̄̄, September 1, 2016, <http://parlmany.youm7.com/News/5/

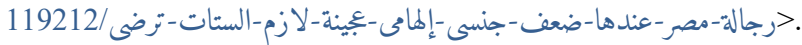

MunÀ 'IZZAT. "Marșad al-ḥuqūq al-iqtișādiyya wa'l-igtimāciyya li'l-nisā' fì 'l-'amal. Al-Taqrīr al-thānī: Al-Taharrush al-ğinsī fĩ amākin al-'amal." [Cairo: New Woman Foundation, June 2016], $<$ http://nwrcegypt.org/wp-content/uploads/2016/06/Observatory-of-the-Economic-and-SocialRights-of-Women-at-Work-15x21-AR.pdf>.

NAJWA YounES. "Video: Street harassment is 'part of our daily lives' as Tunisian women." Tunisia Live, April 5, 2016, <https://web.archive.org/web/20171102195041/http://www.tunisia-live.net: 80/2016/04/05/video-street-harassment-part-of-the-daily-experience-of-tunisian-women>.

AL-NiMR, Isrā̄. "Innahum yaqra'ūn Walīd Dīdā." Akhbār al-Adab, February 12, 2016, <https:// esraaelnemr.wordpress.com/2016/02/12/إنهم-يقرأون-وليد-ديدان.

NŪR HĀNIM. "Fīh banāt fī Mașr shaqyāna wi-ağda' min 100 rāğil qā'id 'a-l-qahwa." Twitter @ Humanityyvoice (sic), November 7, 2016, <https://twitter.com/Humanityyvoice/status/ 795618356355284992>.

QuiLLEN, Stephen. “Cross dressed Halloween teens allegedly beaten and charged by police.” Tunisia Live, November 3, 2016, <https://web.archive.org/web/20161106035606/http://www.tunisia-live. net:80/2016/11/03/hammamet-police-accused-of-beating-and-jailing-transgender-teen>.

RAḤMA ḌıĀ̄'. "Taymūr al-Subkī: bağīb ḥa?? il-riğğāla... wa-lam atalaqqa ayy istid'ā' li'l-taḥqīq." Așwāt Mașriyya, February 15, 2016, <http://www.aswatmasriya.com/news/details/59630>.

jais 21 (2021) - Themed Section In2016: *319_*338 
[RFI =] N. N. « Droits des femmes: la Tunisie fête les 60 ans du Code du statut personnel, » RFI, August 13, 2016, <http://www.rfi.fr/fr/afrique/20160812-code-statut-personnel-tunisie-droits-femmes-60ans>.

RiHAB, «Tunisie: Quand la chasse aux couples non mariés pratiquée par une frange de la société et permise par l'Etat tue », Al Huffington Post Maghreb - Tunisie, August 3, 2016, <https:// web. archive.org/web/20160802221452/http://www.huffpostmaghreb.com/2016/08/01/tunisie-chassecouple_n_11296512.html>.

[RT ARABIC =] N. N. "Tūnis... Imra’a fī manșib amnī muhimm li-awwal marra." RTOnline, August 21,

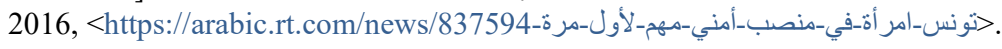

[al-ṢADÀ =] N. N. "Fī șaffa li'l-nukhba al-yasāriyya al-mutațarrifa fî Tūnis wa [sic] al-āālam al-'arabī, Almāniyā tuțabbiq mabda' al-faṣl bayn al-jinsayn 'alà qițāātihā.” al-Ṣadà, March 31, 2016,

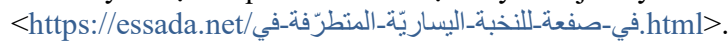

AL-SA IDANI, AL-MANJI. "Irtifāa nisbat al-bațāla fì Tūnis khilāl al-niṣf al-awwal min 2016." al-Sharq al-

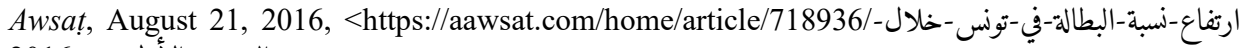
2016- النصف-الأول-من.

ȘAFIYYA MuniR. “"Ma'an riğālan wa-nisāan fĩ muwāğahat al-'unf ḍidd al-mar'a' mubādara li'l-ḥadd min al-'unf didd al-mar'a." al-Monitor, June 2, 2016, <https://www.al-monitor.com/pulse/ar/ originals/2016/06/egypt-men-women-initiative-counter-violence-against-women.html>.

ȘAFIYYA MuNiR. "Mishrat al-khitān aqwà min al-qānūn." al-Monitor, September 27, 2016, <https:// www.al-monitor.com/pulse/ar/contents/articles/originals/2016/09/egypt-fgm-prison-terms-femalegenital-mutlilation-women.html>.

SAMĪKA, Muḥsin. “al-Sīsī yaltaqī ‘Fatāt al-'araba' fì Qașr al-Ittihāaidiyya.” al-Maṣrī al-Yawm, November 13, 2016, <https://www.almasryalyoum.com/news/details/1039734>.

SAMĪrA SA'īD. "Ma-ḥaṣal-sh ḥāğa - fīdēō klīb." Rotana, May 13, 2016, <https://youtu.be/ VFs296Tfzn0>.

SĀRA ȘALĀḤ. "Law qaḍayt al-Falāntain sinğel istacidd... al-ihtimām fì muqaddimat hāshtāğ "Ashān ilbint tihibbak'." al-Yawm al-Sābic, February 15, 2016, <https://www.youm7.com/story/2016/2/

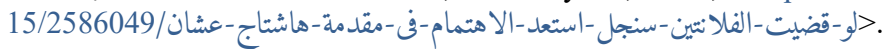

SBoul, Amina. "Opinion: What women wear is none of your business." Tunisia Live, April 25, 2016, $<$ https://web.archive.org/web/20171001215223/http://www.tunisia-live.net/2016/04/25/opinionwhat-women-wear-is-none-of-your-business>.

SHĀDİ SURŪR. "Taitānīc: al-nuskha al-'arabiyya.” Shadi Srour Youtube Channel, September 11, 2016, $<$ https://youtu.be/iXn-eECUi2g $>$.

AL-SHARĪF, Ḥamdī. “'al-Sulța - al-ğasad' - al-muqaddas-... 'arḍ wa-taḥlīl kitab ‘Dawā̄ir al-taḥrīm' li'ldoktōr Hasan Hammād.” al-Hiwār al-Mutamaddin, March 3, 2016, <http://www.ahewar.org/ debat/show.art.asp?aid=511301>.

SHARĪF ABŪ 'L-FAḌL. "al-Nā’ib al-'āmm ya’mur bi-ḍabṭ wa-iḥ̣ār Taymūr al-Subkī bi-tuhmat ihānat sayyidāt Mișr." Bawwābat al-Ahrām, February 16, 2016, <http://gate.ahram.org.eg/News/ 858646.aspx>.

[SZ =] N. N. „Kontroverse um Frauenabteile in der Regionalbahn,“ Süddeutsche Zeitung, March 24, 2016, <https://www.sueddeutsche.de/reise/mitteldeutsche-regiobahn-kontroverse-um-frauenabteilein-der-regionalbahn-1.2921856>.

TARFA, Inel. "Challenging the norm: Street harassment and plus size clothing." Tunisia Live, August 31, 2016, <https://web.archive.org/web/20160901143416/http:/www.tunisia-live.net/2016/08/31/ challenging-the-norm-street-harassment-and-plus-size-clothing $>$.

jais • 21 (2021) - Themed Section In2016: *319_*338 
'UMAR SA ĪD. “ “Āmilāt al-ğins fĩ Miṣr: nabî̀ al-hawà wa-nashtarī qahran.” Madà, November 5, 2014

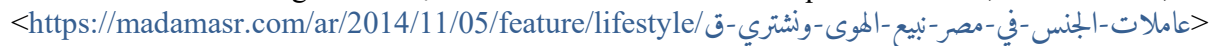
[NB: Though from 2014, this remained one of the most popular articles on Maḋa in 2016].

VASWANI, Miriam. "Secrets of the Medina: Bureaucracy and the bordello." Tunisia Live, August 10, 2016, <https://web.archive.org/web/20160811152124/http://www.tunisia-live.net/2016/08/10/ secrets-of-the-medina-bureaucracy>.

WiKĀLAT TŪNIS IFRĪQIYĀ LIL-AnBĀ’ (Agence Tunis Afrique Presse). "Mashrūe qānūn șādaqa ‘alayhi Majlis Wuzarā': al-sijn 'ām li-kull man ya'mid ilà muḍāyat imra'a fì makān 'umūmī." Shams $F M$,

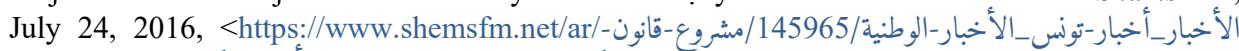

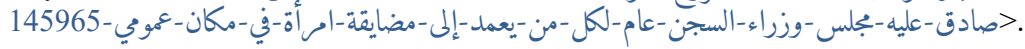

Y.N. « Sexualité : La vérité sur les relations extraconjugales des couples tunisiens. » Kapitalis, August 30, 2016, <http://kapitalis.com/tunisie/2016/08/30/sexualite-verite-sur-les-relations-extraconjugales-descouples-tunisiens/>.

Zap Tharwat ft. Amina Khalil. "Nūr." Axeer YouTube channel, November 25, 2016, <https:// youtu.be/7N5oVNo-oUI>.

\section{Films}

Jeanne d'Arc Mașriyya (Egyptian Jeanne d'Arc). By Īmān Kāmil. Egypt 2016.

Nawwāra (Nawara). By Hāla Khalīl. Egypt 2016.

Nhibbik Hādī (Hédi). By Muhammad Bin 'Ațiyya. Tunisia 2016.

Al-Nușūr al-șaghīra (Little Eagles). By Muḥammad Rashād. Egypt/Lebanon 2016.

Nihāyāt sa īda (Happily Ever After). By Nadà Riyāẹ and Ayman al-Amīr. Egypt 2016.

Sheikh Jackson. By 'Amr Salāma. Egypt 2017.

Zahrat Halab (The Flower of Aleppo). By Rị̣à al-Bāhī (Rida Behi). Tunisia 2016.

\albrecht.hofheinz@ikos.uio.no 